\title{
Integrated and systemic management of storm damage by the forest-based sector and public authorities
}

\author{
Simon Riguelle ${ }^{1,2} \cdot$ Jacques Hébert $^{1} \cdot$ Benoit Jourez $^{2}$
}

Received: 7 January 2016 / Accepted: 26 May 2016 / Published online: 7 June 2016

(C) INRA and Springer-Verlag France 2016

\begin{abstract}
- Key message Integrated and systemic management of wind damage risk can help to address decision-making requirements, mitigate economic impacts of storms, and improve collective well-being of the forest sector. In this context, public authorities should actively act to enable flexible decision-making and strengthen the resilience of the forest sector facing destructive storms.

- Context Destructive storms are among the major threats to forest-based economies in Europe. Over three decades, the topic has gradually moved to the top of the forest community's agenda but with little coordination among stakeholders and limited response from public authorities.

- Aims The paper's goals are to identify key challenges in the current windthrow management framework and present a blueprint for how to progress in the settlement of regional strategies. - Methods SWOT analyses are used to highlight relevant issues and opportunities in classical approaches from both the forest-based sector and public authorities' perspectives.

- Results Despite the large body of knowledge that allows decision-makers to react promptly after huge storms, strategic responses still suffer from too individual and fragmented decisions and a lack of holistic economic assessments. To tackle
\end{abstract}

Handling Editor: Barry Alan Gardiner

Contribution of the co-authors Co-authors are $\mathrm{PhD}$ thesis' supervisors and have thoroughly reviewed the paper.

Simon Riguelle

simon.riguelle@outlook.com

1 Unit of Forest Resources Management, Department of Biosystem Engineering, Gembloux AgroBio Tech, ULG, Gembloux, Belgium

2 Public Service of Wallonia, Laboratory of Wood Technology, Wallonia, Belgium these issues, the paper suggests using systemic and integrated risk management approaches. It also presents the ways to enhance the forest-based sector's resistance and resilience towards economic shock and supports decision-making with the help of systemic analysis.

- Conclusion This shift of paradigm is one of the key requirements in optimizing the way of dealing with storm damage, but public authorities should concur with it more actively by improving decisional and administrative frameworks.

Keywords Windthrow $\cdot$ Risk management .

Decision-making

\section{Introduction}

Worldwide, windstorms are among the major abiotic threats to planted forests (Payn et al. 2015), and in Europe, they have contributed to more than the half of the total damage to forest resources since 1950 (Schelhaas et al. 2003). Even though wind hazards are natural drivers of forest ecosystems (Mitchell 2013), destructive storms that occur over large areas in managed forests lead to severe economic losses for the forest-based sector (Björheden 2007) and offset benefits resulting from higher forest productivity (Fares et al. 2015). For example, the total insured losses, including forestry, due to the storm series of 1999 exceeded $€ 10$ billion (Munich Re 2002). The total economic losses resulting from those events were estimated at around twice as much (Pinto et al. 2007). From an industrial angle, destructive storms are usually defined as hazards that blow down $100 \%$ or more of the average annual harvest at the scale of industrial supply (Forestry Commission Scotland 2014). This sudden amount of timber to cope with threatens the normal functioning of forest-based activities (Valinger et al. 2014), disrupts the classical 
management and decision-making processes (Angst and Volz 2002; Broman et al. 2009), and consequently causes critical situations within public and private organizations (Drouineau et al. 2000; Birot et al. 2009). Regarding timber markets, prices and supply may be heavily impacted over the long run when several supply areas are experiencing severe damage at the same time (Costa and Ibanez 2005). From an environmental perspective, wind disturbances may cause a huge reduction of forest carbon sinks (Lindroth et al. 2009), lead to pest outbreaks (Wermelinger et al. 2013), or weaken the production of goods and services of forests in damaged areas (Lindner et al. 2010). In addition, the society is also affected by the consequences of storms, i.e., occurrence of civil casualties, alteration of landscapes, and of living conditions (Blennow and Persson 2013).

In light of those potential impacts, active management of storm damage risk should appear logical. Paradoxically, even though destructive storms have been part of the history of European forests for a long time (Corvol 2005), this only became obvious in the 1990s, after a succession of shock events that led to questions regarding major changes in forest management (Birot 2002; Veenman et al. 2009). As a result, literature on risk management in forestry exponentially increased in the 2000s (Yousefpour et al. 2012), and a large body of knowledge is now available. This new paradigm within the forest community is also driven by several external factors. One of them is the macro-economic context, particularly the need to stay competitive in a globalized timber market and thus to limit the costs related to natural hazards (Meyer et al. 2013). Other impulses ensued from uncertainties linked to expected impacts of climate change on forest storm damage (Spathelf et al. 2014; Keenan 2015; Schou et al. 2015). Among others, the potential shift in winter storm frequency and severity (Fink et al. 2009; Schwierz et al. 2010), the continuous increase of the economic value at risk owing to the capitalization of growing stock (Nabuurs et al. 2007), and the higher vulnerability of forest stands (Campioli et al. 2012) are expected to increase the risk of damage. Societal changes also generate increasing economic losses from natural disasters (Barredo 2010). Therefore, in accordance with the "Risk Society" concept (Beck 1992), the management of hazards and insecurities in our modern societies tends to be one of the main preoccupations of public decision-makers (Brunet 2007). Nowadays, in this new perspective of modernity, politics are more prone to deal with the after-effects of huge storms and actively take part in the process (Barthod and Barrillon 2002). Whatever the initial motivation, it is now clear that both the forest-based sector and the public authorities cannot avoid addressing storm damage risk. The question is how to do this soundly and effectively.

Through the years, a methodological framework to address storm damage risk in forestry was gradually formalized on the basis of the classical theory of risk management (Haimes
2011) and international standards (ISO 31000 2009) and was used in several papers (Gardiner and Quine 2000; Kamimura and Shiraishi 2007; Schelhaas et al. 2010; Hanewinkel et al. 2011). This framework consists of an iterative assessment process that allows decision-makers to quantify risk - where the term risk encompasses the large variety of risks resulting from destructive storms - and implement mitigation strategies in order to reach the desired level of residual risk. For this latter purpose, decision-makers have to know what the options are, what the costs and benefits are, and the residual risk associated with policy options (Kaplan and Garrick 1981). In a second step, if the residual risk remains too high to be acceptable, tools and procedures to support crisis management may be developed, such as decision support systems, contingency plans, trainings, and exercises. Finally, if the destructive storm occurs, the response phase will be activated. It first consists of an immediate crisis response period with a special focus on emergency and rescue operations, timber damage assessment, and safeguarding measures. After the emergency phase, a public strategy should be implemented to support the forestbased sector. Again, public decision-makers will have to choose between a set of strategies encompassing the particular interests of stakeholders and public constraints. The more efficient the strategy is, the quicker the forest-based sector will recover from the shock and stabilize to a new equilibrium.

Despite the methodological improvements and the large body of literature addressing specific storm-related issues in forestry over the last 15 years, several papers recently reported the need to improve decision-making and management of storm damage at the strategic level (Gardiner et al. 2010, 2013; Landmann et al. 2015). However, as indicated previously, storm damage management is a highly complex, uncertain, and ambiguous process because of the multiplicity of risks, stakeholders, goals, and beliefs. As it is impossible to eliminate those elements from the risk management process, new approaches to address them effectively must be provided to the forest-based sector and the public authorities. Furthermore, the role of public authorities has to be clarified in regard to the forest community's expectations. Indeed, in the past, initiatives from the forest community did not always receive the expected responses from public authorities (Birot et al. 2009). In this context, it seemed relevant to re-open the debate on how windthrow crisis management may be improved at the strategic level and what the role and interactions of the forest community and public authorities should be in this effort. The target of this paper is thus to provide a blueprint for how to progress in the future, identify where the priorities are, and suggest how some of them should be addressed. The first step is to identify issues and opportunities for stakeholders, using strengths, weaknesses, opportunities, and threats (SWOT) analyses based on recent storm experiences and the relevant literature. The second is to present a holistic approach for addressing storm damage risk at the 
regional (or national) level and describe the way to mitigate risk and support decision-making according to this framework. A focus on the specific role of public authorities is presented in a third step.

\section{Strategic issues and opportunities}

\subsection{Methodology}

SWOT methodology was chosen to identify the current strengths, weaknesses, opportunities, and threats in the storm damage management process from both the forest-based sector and public authorities' perspectives. This allows the internal factors that can be handled directly by decision-makers from both groups to be distinguished and identifies the external elements they need to address to build their risk management strategy. It also contributes to highlighting common features and reveals the inherent relationships between these two types of stakeholders. A broad literature search focusing on "risk and crisis management in forestry" was done using different search engines. This resulted in a list of approximately 250 relevant papers. However, few of them provided a global analysis of storm damage crisis approaches. Therefore, several ex-post crisis evaluations - either governmental reports or publications by public bodies and private institutions (see Table 1) - were also reviewed. Analyses of recent storm crises in European countries are indeed good entryways to identifying limits and failures in classical approaches (Trauman 2002).

\subsection{SWOT analyses}

Table 2 presents the outputs of the two SWOT analyses. Only the most significant topics regarding strategic decisionmaking and crisis management were retained after the review process. Tactical and operational issues are not considered, except as they arose because of strategic concerns. The results are briefly discussed below.
Forest managers usually have a good perception of the exceptional nature of destructive storm events and thus are prone to react quickly after calamities (Direction des Forêts 1987; Swedish Forest Agency 2006). The downside to this strong empirical knowledge may be a reluctance to manage actively the risk of storm damage, as stakeholders generally consider windstorms from a fatalistic perspective (Peyron et al. 1999). At the same time, knowledge about the operational management of windthrows has strongly increased in the last decades because of former crisis experiences and an increasing scientific focus on this topic. Numerous technical handbooks - sometimes released in emergency just after a storm-support decision-makers and managers (Forest Windblow Action Committee 1988; FAO/ECE/ILO 1996; Pischedda 2004; Odenthal-Kahabka 2005; OFEV 2008; Oosterbaan et al. 2009). However, the sharing of knowledge between scientists and practitioners can be problematic. The Storm Handbook (Odenthal-Kahabka 2005; Chtioui et al. 2015), which evolved progressively from a print to an online version, is a good illustration of how information policy about windstorms has changed over the years to address the lack of accessibility and applicability of information (Hartebrodt 2014).

As for disaster risk management in general (Gopalakrishnan and Okada 2007), the main flaw results from the diversity of stakeholders' beliefs, interests, and goals which complicate the post-storm crisis response. The high fragmentation of forest estates and the multitude of owners, in both private and public forests, also make it difficult to settle on a common strategy. As an illustration, the fragmentation of forest estates and the rights of ownership were considered major hindrances to timber salvage during previous crises (Lesbats 2002). The recurring lack of liquidity also exacerbates the stakeholders' dependence on public compensation. Therefore, the competition for public subsidies in the aftermath of windstorms may enhance individualistic behavior (Brunette and Couture 2008). As a result, the forest-based sector often implements uncoordinated and

Table 1 Selection of ex-post evaluations of storm crisis management strategies in Europe

\begin{tabular}{lll}
\hline Scope & Storm (Year) & References \\
\hline UK & The Great Storm (1987) & MAFF (1988); Grayson (1989); Harmer (2012) \\
Europe & Selection of storms & Gardiner et al. (2010, 2013) \\
France & Lothar-Martin (1999) & Drouineau et al. (2000); Barthod and Barrillon (2002); \\
& & Lesbats (2002); Birot et al. (2009); FIBOIS (2010b) \\
& Klaus (2009) & Nicolas (2009); Laffite and Lerat (2009) GIP ECOFOR (2010); \\
Germany & Lothar (1999) & Bavard et al. (2013) \\
Sweden & Gudrun (2005) & Hänsli et al. (2003) \\
Switzerland & Lothar (1999) & Swedish Forest Agency (2006) \\
& & Bründl and Rickli (2002); Hammer et al. (2003); \\
& & Hänsli et al. (2003); Raetz (2004)
\end{tabular}


Table 2 Overview of most frequent strengths, weaknesses, opportunities, and threats regarding strategic decision-making and management of storm damage by the forest-based sector (FBS) and public authorities (PA)

\begin{tabular}{|c|c|c|}
\hline & Forest-based sector (FBS) & Public authorities (PA) \\
\hline \multirow[t]{3}{*}{ Strengths } & - Strong operational know-how & - Financial capacity \\
\hline & • Strong empirical knowledge & - Legislative power \\
\hline & - Large body of scientific knowledge & - Regulatory levers \\
\hline \multirow[t]{7}{*}{ Weaknesses } & - Reluctance to manage risks & - Lack of public risk governance \\
\hline & - Limited common strategy & - No integrated policy for forest risks \\
\hline & - Short versus long-term goals & - Unclear storm management strategy \\
\hline & - Private versus public behaviors & - Fragmented and unbalanced approach \\
\hline & - Lack of financial liquidity & - Complexity of cost-efficiency analyses \\
\hline & - Few long-term impact assessments & - Poor cooperation with other regions/states \\
\hline & - Share of knowledge (all levels) & - Staff, structures, and facilities \\
\hline \multirow[t]{7}{*}{ Opportunities } & - Advanced decision support systems & - Advanced decision support systems \\
\hline & • Innovation capacity & - Innovation capacity in the FBS \\
\hline & - Development of ICT solutions & - Development of ICT solutions \\
\hline & - Higher expectations towards forest & - Societal expectations towards forests \\
\hline & - Coordination initiatives & - Increase of societal risk awareness \\
\hline & - Increasing scientific knowledge & - Advanced economic impact assessments \\
\hline & - Emergence of new markets & - Role of forests in climate mitigation \\
\hline \multirow[t]{9}{*}{ Threats } & • Macro-economic context & - Macro-economic context \\
\hline & - Climatic and market uncertainties & - Public expectations \\
\hline & - Change resistance & - Change resistance \\
\hline & - Timber market disruption & - Shrinkage of financial resources \\
\hline & - Reduction of financial support & - Globalization of timber market \\
\hline & - Inappropriate legislation & - EU competition rules \\
\hline & - Rigid decisional framework & - Uncontrolled ideological issues \\
\hline & - Loss of experienced people & - Emotional management \\
\hline & - Lack of solidarity & - Uncertain impacts of climate change \\
\hline
\end{tabular}

fragmented strategies, which is a major source of inefficiency. Insurance issues also lead to ambiguous behaviors. For instance, too high premiums compared to forest investments often deter owners from subscribing to insurance (Brunette et al. 2015) and make them dependent on state aid in case of storm damage. Furthermore, when insurance does exist, it compensates primary damage on the forest resource but rarely subsequent damage resulting from complications (Holecy and Hanewinkel 2006).

In the past, diverging interests between stakeholders have also weakened the sector's credibility vis-à-vis the public authorities and complicated negotiations with them (Lesbats 2002). Individual and sometimes antagonistic strategies contributed to slowing down recovery from storm crises (GIP ECOFOR 2010), while fragmented approaches have led to a dispersion of financial resources without knowing whether individual measures are cost-effective (Caurla et al. 2015). Consequently, public mitigation measures may cause competitive distortion between stakeholders if the global economic welfare of the forest-based sector is ignored during the decision-making process (Ananda and Herath 2009). Former experiences revealed that even if public authorities hold the strategic levers, they lack supporting tools and information to build integrated strategies (Gardiner et al. 2010). Usually, forest policy-making follows its own logic, based on diverging interests and values (Winkel and Sotirov 2015). Even though risk awareness is increasing, significant gaps remain in public risk governance, and public policies do not often encompass risk as the driver of decision-making processes (Blennow 2008). In a storm crisis context, it results in unpreparedness, overhasty strategies, and the spread of all possible grants (i.e., harvesting, storage, replanting, and marketing subsidies) without cost-efficiency assessments. Owing to the emergency context, crisis management measures are often disconnected from the prevailing macro-economic context (Bavard et al. 2013) although they are determinants of the forest sector's resistance and resilience. In fact, without appropriate economic analyses, the pros and cons of mitigation strategies are not easy to predict. The restricted availability of country-level information on 
disturbances can make implementing multi-risk strategies even more difficult (van Lierop et al. 2015).

Fortunately, new conditions for storm damage management are emerging. The accessibility to advanced decision support systems (Diaz-Balteiro and Romero 2008; Reynolds et al. 2008; Marques et al. 2013b; Segura et al. 2014) and the development of powerful information and communications technology (ICT) solutions (Reynolds et al. 2005) should ease the strategic management of storm damage by both the forest-based sector and public authorities. Innovation capacity in the timber industry will open new market opportunities for windblown timber and provide favorable market and policy conditions (Buttoud et al. 2011). However, as stated by Nilsson (2015), forest policy-making is not yet an affair between the sector and the public authorities, as manifold stakeholders claim interests and rights associated with the forest. Societal requirements are double-edged elements because even if they increase the role of forest ecosystems, they also force the public authorities and the forest sector to cope with ideological expectations (Ananda and Herath 2009). Therefore, storm calamities and associated casualties are likely to cause overreactions and political claims (Raetz 2004).

From an economic angle, a slump in market conditions associated with lower financial public support may threaten the effectiveness of risk management approaches when windstorms occur. Uncertainties relative to market behavior and long-term wood procurement (Schwarzbauer and Rauch 2013) are among those economic issues. From the perspective of decision-making, rigid administrative and decisional frameworks, as well as uncontrolled ideological issues (Raetz 2004), may jeopardize rapid support to the forest sector. Finally, the loss of experienced people (Hartebrodt 2014) and fading memories (Harmer 2012) could make the risk management process less obvious and urgent for forest-based sector stakeholders. Indeed, although damaging windstorms occurred on average twice a year at the European scale during the last 60 years (Gardiner et al. 2010), their frequency is not equally shared at the regional scale. For countries that did not experience destructive storms for decades, such as Belgium, it could be a major hindrance to actively manage the risk (Riguelle et al. 2011). Uncertainties linked to climate change will require flexible and priority-setting approaches on the one hand (Millar et al. 2007), and on the other hand will require a mixed strategy, including adaptation and mitigation measures (Seidl and Lexer 2013). Even though uncertainties linked to future climate tend to push risk management issues to the top of the forestry agenda, they remain potentially a major source of inertia (Petr et al. 2014).

\section{Integrated and systemic storm damage management}

\subsection{Advocacy for integrated storm damage management}

Integrated management of risks in forestry is an emerging trend that aims to consider simultaneously, at each level of decision, every component of the risk management process together with external constraints and the expectations and beliefs of various stakeholders (Orazio et al. 2014). This definition implies that decision-makers must ideally handle together the large variety of risks that forests face in order to reduce the global threat for the forest sector (Drouineau et al. 2000). Interactions between risks are crucial to consider because a particular response to a specific risk may enhance resistance to one damaging agent while increasing susceptibility to other causes of damage (Jactel et al. 2009). A global vision also allows diversification of the portfolio of mitigation measures and reduction of the overall residual risk for forest economies (Birot 2002). Furthermore, one of the key outputs of such integrated risk management approaches is to understand and combine the desires and beliefs from all stakeholders under external constraints (Yousefpour et al. 2013; Blennow et al. 2014). As highlighted by previous SWOT analyses, storm damage management is characterized by a high level of complexity, which is exacerbated by the manifold stakeholders, economic goals, and personal beliefs. Agreeing on a common strategy for storm damage management is thus very tricky. To tackle this major challenge, we suggest forest policy and decision-makers should take the plunge and turn from an individual to an integrated management of storm damage risk.

Integrated approaches aim to combine several disciplines and involve different stakeholders operating in their own sphere (or sub-systems, see below) across different spatial and temporal scales (Fig. 1). Within this framework, storm damage risk can be addressed specifically, provided interactions with other risks (i.e., risk of pest outbreaks, fire, or game damage) are kept in mind (Fermet-Quinet 2013). By analogy with the Integrated Natural Resources Management (INRM) concept (see e.g., Lal et al. 2002; Sayer and Campbell 2002), an Integrated Storm Damage Management (ISDM) methodology should thus be built. Nevertheless, because integrated approaches embrace, by definition, many topics at the same time, decision-makers need methodological supports to handle this complexity. The main requirements for applying an integrated framework are generally considered twofold: on the one hand to incorporate stakeholders' requirements and on the other hand to provide decision support methodologies (Lal et al. 2002).

Regarding stakeholders' targets, there is no simple method for balancing different concerns when facing complex situations (Aven 2009). The holistic approach proposed by Aven 
Fig. 1 Generic framework for implementing integrated storm damage management (ISDM) approach (adapted from Campbell et al. 2002)

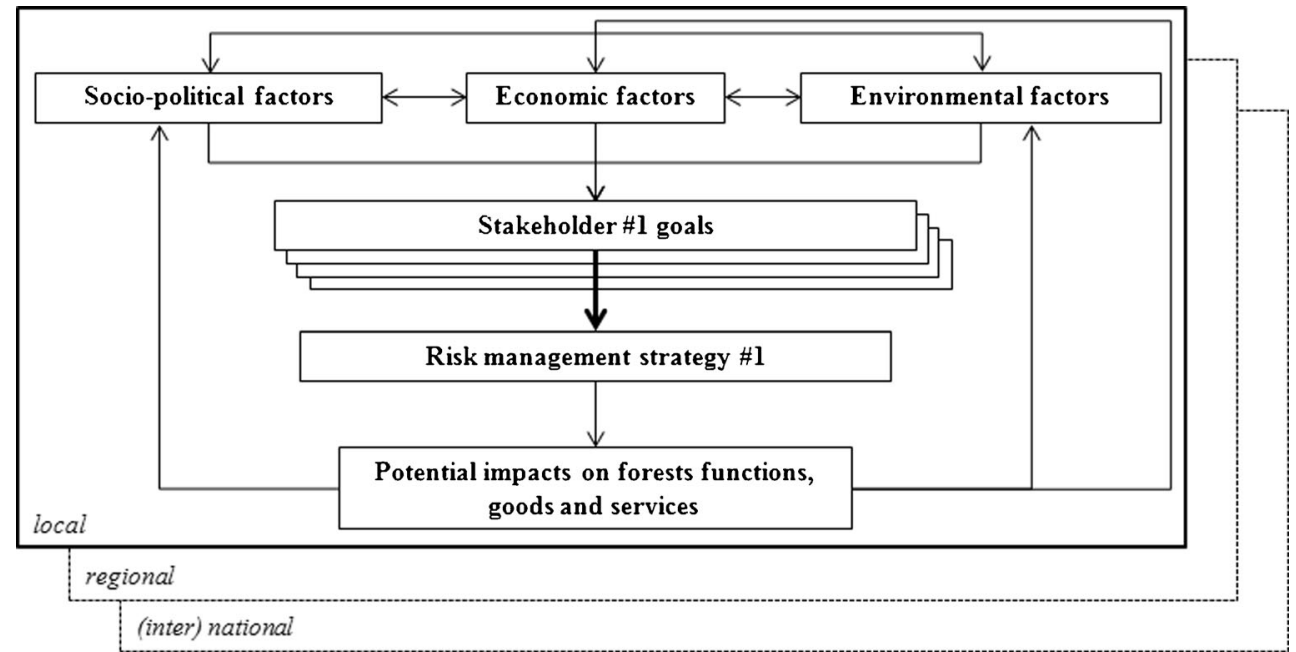

and Kristensen (2005) considers risk in its full dimension, taking into account possible consequences and associated uncertainties. An output-oriented approach (Greiving et al. 2012) could also help to determine "agreements on objectives" among stakeholders. In this latter approach, dialogue among experts, stakeholders, and decision-makers is fundamental in order to guarantee inclusion of all perspectives (values, opinions, and claims) in the risk analysis process. According to Greiving et al. (2012), a win-win situation among involved stakeholders could emerge with regard to reaching an agreement on common goals and actions to achieve them in due course. Furthermore, participatory approaches could facilitate stakeholders' involvement in the decision-making processes (Ananda and Herath 2003) and increase the quality of decisions (Beierle 2002). This is mainly relevant to multi-stakeholder decision-making processes (Garcia-Gonzalo et al. 2013) in which the willingness to share strategic information is a key factor of success (Marques et al. 2013a). For natural risks, when uncertainty in the decisions made is coupled with a high degree of conflict among the affected interest groups, combining participatory planning and structuring instruments like multi-criteria decision analysis methods (Mendoza and Martins 2006) could serve to incorporate the risk preferences of stakeholders for policy-building (Gamper and Turcanu 2009). Previous approaches to reaching common goals about risk management are promising and should be applied in integrated storm damage management. However, the success of an integrated storm damage management strategy will also lie in the ability to identify balanced strategies at an aggregated level of decision-making.

\subsection{Towards systemic approaches}

In order to support the ISDM process and identify, in the portfolio of potential crisis measures, the most efficient way to reach mid- and long-term collective targets, we suggest that a systemic approach should be used. Indeed, the complexity of storm damage management can be handled by using systems theory, since it can be conceptualized in a systemic way. In systems theory - also known as systems thinking - the complexity of these kind of systems can be considered and their dynamics - the interaction between elements - can be observed through simulations (de Rosnay 1997). According to that, systemic analysis can be used to identify, optimize, and control the system, while taking in account multiple objectives, constraints, and resources (Heylighen and Joslyn 1992). Systemic analysis is thus a powerful tool for specifying different storm damage mitigation scenarios, together with their associated risks, costs, and benefits. However, it requests to determine first the scale, boundaries, inputs, outputs, and internal processes of the system at stake.

Scaling issues are crucial as the strategy might be assessed as being negative at one scale but positive at another (Sayer and Campbell 2002). The analytic scale could also restrict the generality and utility of findings (Lovell et al. 2002). Regarding storm damage management, there is no unique appropriate level to judge the overall benefits of a strategy; therefore, several systemic scales can be considered, according to the decisional level (supranational, national, or regional) or management level (strategic, tactical, or operational). Whatever the scale considered, it is fundamental to conceptualize the system and its relationships with sub- or metasystems and remind that decisions at this specific scale can also influence those other systems. Example of a basic system including a succession of forest operations (salvage logging, transport, storage, processing), partially bound up with and affected by up- and downstream decisions as well as by the external context is given in Fig. 2. In this example, the system encompasses successive steps of regional forest-wood chains and is thus composed of several sub-systems (Riguelle et al. 2015). Its behavior is influenced by regional, national, and 
Fig. 2 Systemic representation of a regional forest-wood chain. In this example, scale, boundaries (dash lines), inputs, outputs, internal processes, and external drivers of the system are represented

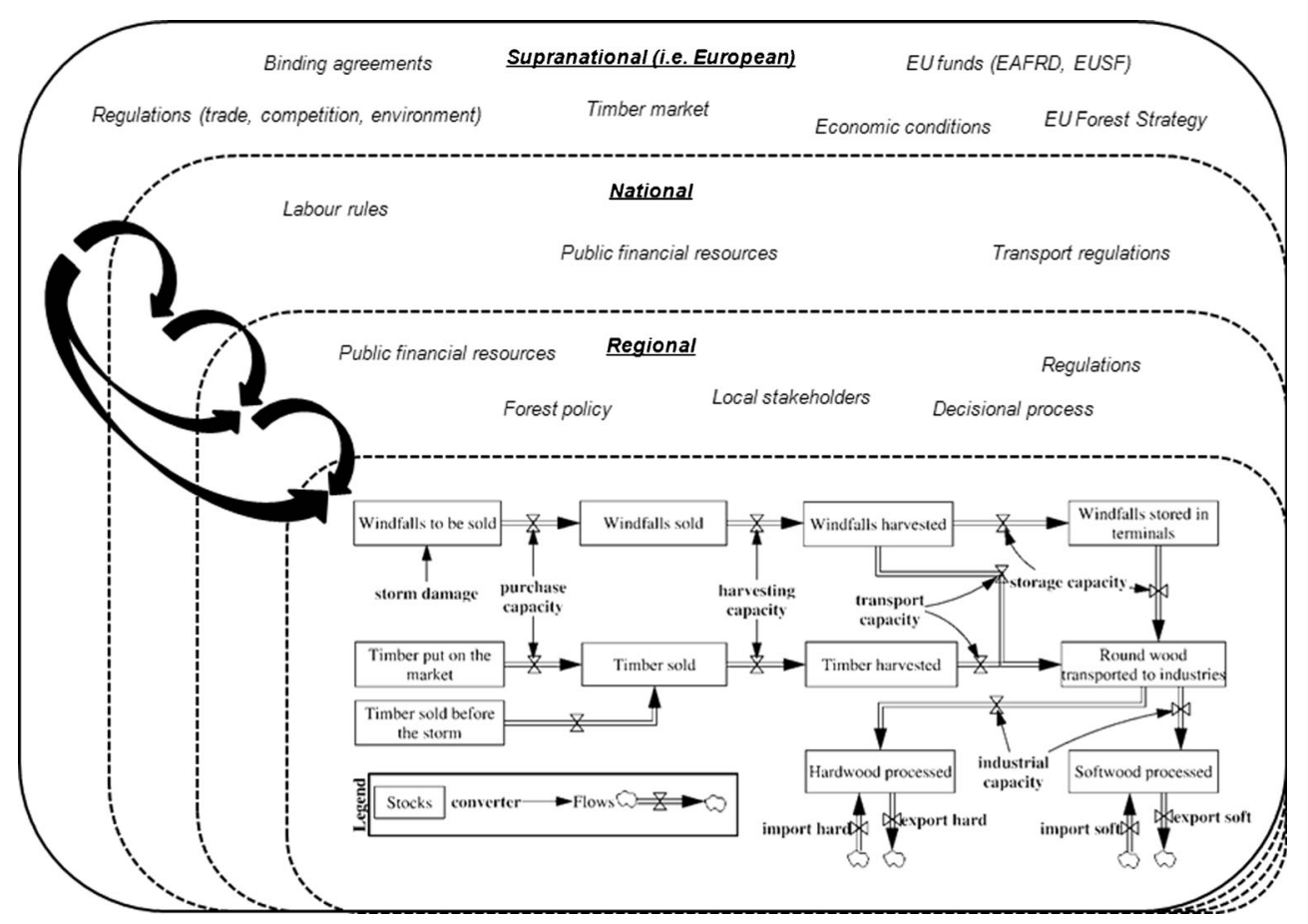

supranational (European) factors. Those external constraints may include political, institutional, financial, environmental, ideological, or social considerations that directly influence the state of the system.

The systemic approach was already suggested by Blennow and Sallnäs (2005) for active risk management in forestry. In their view, the forest-based sector is a wide system whose functioning is influenced by individual behaviors and which interacts with elements outside the system (Blennow and Sallnäs 2005). Systemic approaches were also used to analyze the impacts of policy reforms on the forest-based sector (Rametsteiner and Weiss 2006a) or to study innovation in the forest sector (Rametsteiner and Weiss 2006b). Regarding storm damage management, the systems thinking concept is also partially applied nowadays. In fact, the first reaction after the storm is to determine if the event is expected to have critical (regional) or limited (localized) impacts on the forest-based sector. Experience usually helps to determine threshold values, expressed in terms of resources impacted by the storm, beyond which the functioning of the forestbased sector will be disrupted (Nieuwenhuis and O'connor 2001) and crisis management should be activated. Traditionally, the initial amount of damage is associated with an expected impact on the timber market and mobilization by comparison to previous windthrow crises.

This kind of systemic reasoning is valuable but oversimplified because it does not take into account the ability of the system to withstand the shockwave. In fact, damage threshold values could evolve between two critical events, due to internal changes within the system resulting from active risk mitigation processes or external constraints. Thus, in a second phase, deeper systemic analysis would still be needed to depict how the functioning of forest-wood chains will change according to a brutal disruption, where the bottlenecks are, and what the consequences will be of strategic action or inaction. Another premise is that within this system, which is a connected network, any individual element will not be able to reach its optimum state if others struggle with the crisis consequences. In other words, the global result is curbed by the weakest link in the chain. From that assumption, it follows that managing storm damage with a systemic approach will improve well-being at the aggregate level, and then could be profitable for each individual. While it does not exclude taking tailored measures with a limited scope to improve the functioning of a specific sub-system (i.e., logging or transport operations) or supporting stakeholders experiencing heavier storm impacts, it compels decision-holders to think globally. Even though the emergence of lone-rangers, who will acquire huge benefits from a crisis situation at the expense of others, is not excluded in this approach, it can be minimized if the crisis management strategy is balanced and the cooperation thereby enhanced (Fischbacher and Gächter 2010).

\subsection{Risk mitigation at the systemic level}

Dealing actively with storm damage risk implies the definition of mitigation strategies based on the level of risk and the risk preference of decision-makers (Gardiner and Quine 2000). At the individual level, each actor can choose between a set of measures to reduce, spread, or manage the consequences of 
Fig. 3 Set of strategies to mitigate impacts of storms on the forest sector at the systemic level

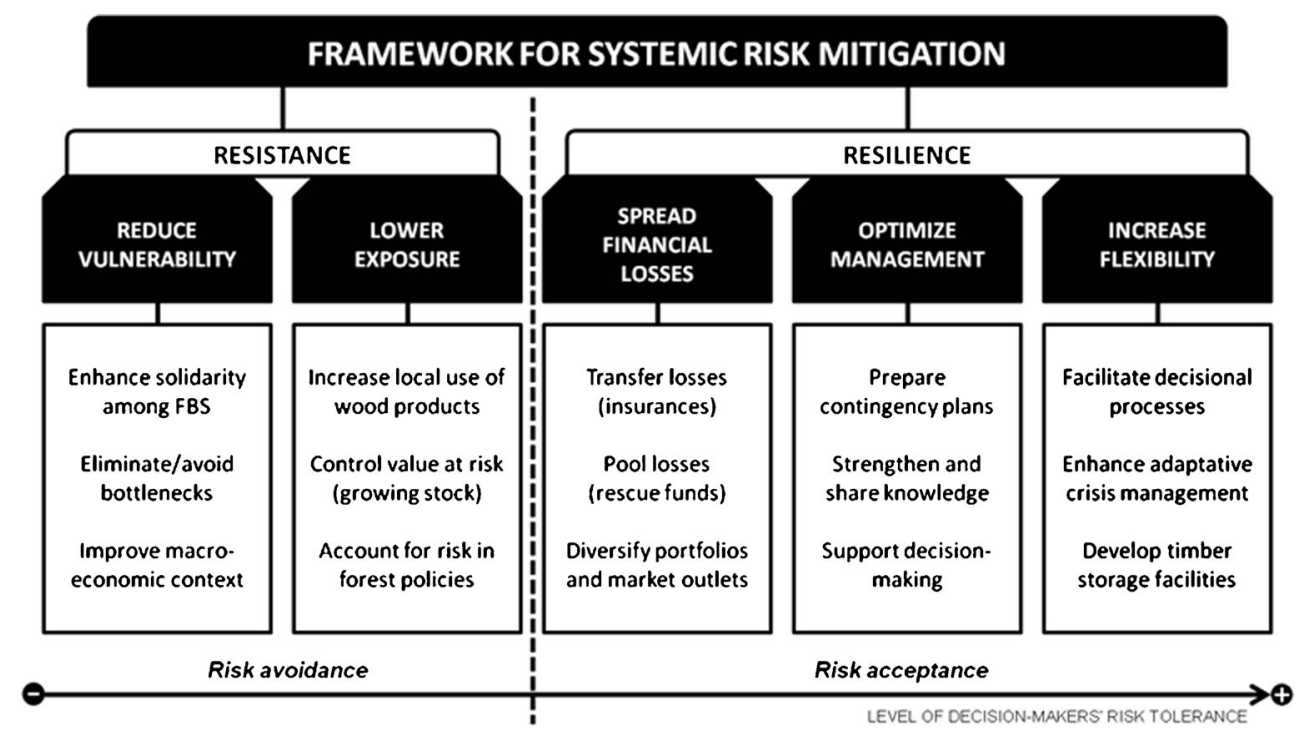

windstorms on his/her business (see Fig. 3). Adaptation and mitigation strategies are well described, especially in regard to forest management (Heinonen et al. 2009; Schelhaas et al. 2010; Lagergren et al. 2012; O'Hara and Ramage 2013; Subramanian et al. 2015). However, the sum of individual strategies does not guarantee the effectiveness of the global strategy, and systemic mitigation measures should be taken as complementary to them. Figure 3 presents some of the most relevant ways to increase both systemic resistance and resilience according to the risk-acceptance level of decision-makers.

The resistance of the system can be defined as its ability to function at close to its normal capacity and to carry on normal operations with minimal disruption after the storm. Resistance could be improved by reducing either the vulnerability or the exposure of the forest-based sector (FBS) at the regional scale (Fig. 3). As mentioned in the previous sections, cohesion among stakeholders is a priority to reduce vulnerability. Another major opportunity to improve systemic resistance is to identify bottlenecks and find the way to address or avoid them before the next crisis. Bottlenecks are the weakest links of a system; therefore, they are good indicators of its viability (Bossel 2002). Practically, legislative, technical, or financial hindrances may be the cause of systemic dysfunctions. However, advanced modeling tools are necessary to lead systemic analysis and identify bottlenecks. From a systemic perspective, increasing the local demand for wood products could facilitate the absorption of damaged timber and lower the pressure on timber markets. It could also contribute partially to a better regulation of the forest growing stock at the regional level, which is a major determinant of the level of damage (Usbeck et al. 2010). More generally, integrating risks in forest policies will have a positive impact on national resistance towards unexpected events (Blennow 2008).
The resilience of the system is its ability to absorb a shock wave in such a way that it can return to a normal state with the least possible delay and with the least possible dysfunction (IPPC 2012; Dymond et al. 2015). Ensuring decisionmakers have a high level of information and preparedness corresponds with the enhancement of this systemic resilience. For these purposes, technical handbooks and contingency plans are key elements. Contingency plans are required to quicken and coordinate the operational and strategic response. Contingency plans developed in recent years for the public authorities (Bartet and Mortier 2002; OFEV 2008; Riguelle 2010; Forestry Commission Scotland 2014; Chtioui et al. 2015) or by the forest-based sector (Lesgourgues and Drouineau 2009; FIBOIS 2010a) illustrate how windthrow crises management may be optimized. Technical guides also facilitate decision-making after the storm. Another option to increase resilience is to improve the flexibility of the system. Past events have shown that too rigid decisional frameworks and administrative procedures (Lesbats 2002) as well as uncontrolled ideological issues (Raetz 2004) may slow down the recovery after destructive storms. Yet, this must not be underestimated in the systemic approach. The development of timber storage facilities which can contribute to softening the stumpage prices' variation (Costa and Ibanez 2005) is also a main option for improving systemic resilience.

Between these two options, a possible middle path is to spread the risk. A possibility is to transfer the financial consequences of storms from one party to another. Compensating losses through insurance is an option for the forest-based sector (Birot and Gollier 2001), but its implementation is slowed down by several issues (Brunette et al. 2015), including the belief that public subsidies will always compensate the losses (Brunette and Couture 2008). Indeed, public authorities used to build rescue funds to pool the risk or mobilize extra budgets to provide financial compensation for storm damage, and 
these safety nets may have reduced the sector's willingness to purchase insurance or invest in risk reduction (Brunette and Couture 2008). Insurability of natural hazards in forestry has already been identified as a prerequisite for risk mitigation (Birot and Gollier) but with limited response from both public authorities and insurers in some countries. Nowadays, the forest-based sector needs clear public commitment about assurance premiums, incentive programs, and self-insurability (Sauter et al. 2016).

\subsection{Assessing systemic impacts of storms}

Taking decisions according to this integrated and systemic framework is not easy for decision-makers, as they have to consider simultaneously internal interactions between stakeholders and external influences. It implies continuously gathering information during the decision-making process and identifying barriers or distortions that arise from decisions or the absence of decisions. To a certain extent, technical handbooks already bring knowledge-based decisional support to decision-makers and can drive decision-making processes. In addition, decision-makers may request aggregated information and calibrate mitigation strategies at the global level. A main requirement to address systemic issues is to provide to decision-makers a deeper understanding about economic knock-on effects of storms. In order to identify expected changes and key levers before windthrow crises, it is recommended that the long-term effects of policy options and the economic context on the forest-based sector are assessed as, for instance, Schwarzbauer et al. (2013) did with a dynamic system model for the Austrian forest sector. Outside the crisis period, mapping the wood harvesting changes, which result from the salvage harvesting that follows destructive storms at an aggregated level (Verkerk et al. 2015), could serve to assess potential economic losses. During the crisis period, from a purely economic angle, the challenge will be to manage stocks in order to smooth fluctuations and, for this purpose, it is necessary to understand how the wood markets react to disturbances (Baur et al. 2004). A model of timber market dynamics after natural catastrophes was also used by Prestemon and Holmes (2004) to explore how US government spending to mitigate economic losses through timber salvage is related to the costs of intervention. This simulation model illustrates how such an approach could, in time, support crisis response and a cash-constrained context (Prestemon and Holmes 2004).

Including the economic dimensions of disturbances in the decision-making processes is a core requirement (Holmes et al. 2008). First, a thorough understanding of overall economic impacts of wind hazards, including damage and risk mitigation costs, is required (Meyer et al. 2013). Assessment of storm economic impacts begins with sound damage assessment procedures at the regional or national level, which is mandatory within the first days to support decision-making (Honkavaara et al. 2013). Whatever the methodology chosen at regional scale (field inventory, aerial, or satellite imagery) estimates, which imply a trade-off between accuracy and swiftness, must only be used to calibrate the crisis response (Riguelle et al. 2011). Indeed, inferring systemic economic impacts from the initial amount of damage is misleading as secondary and tertiary damages are not taken in account, nor are the benefits of mitigation strategies. For example, secondary damage resulting from bark beetles outbreaks in the follow-up to large disturbances (Wermelinger et al. 2002) are responsible, on average, for extra damage of between 10 and $25 \%$ of initial wind damage (Stadelmann et al. 2013). Thom et al. (2013) demonstrated that for every cubic meter of bark beetle damage in the current year, $0.56 \mathrm{~m}^{3}$ of additional bark beetle damage is expected in the following year. This not only means that sanitary concerns must be integrated as soon as possible in the decision-making scheme (Wermelinger et al. 2013), but it emphasizes the need for an advanced cost-benefit analysis to inform decisions. For example, it could be useful to assess the need to make salvage cuttings in partially damage stands in regards to the potential secondary losses (Bouget and Duelli 2004).

Economic assessments also implies quantifying in monetary terms the public benefits and externalities generated from forests' goods and services (Buttoud 2000). As an illustration, destructive storms in forests can cause a huge reduction of carbon sinks (Lindroth et al. 2009) that would have been far more costly if created in other ways (Canadell and Raupach 2008). Therefore, they can cause additional losses for owners if they have to repay emissions units (Moore et al. 2013). Such considerations must be included in decision-making processes. Nonetheless, assessing the economic effects of disturbances requires models with a considerable scope (Toppinen and Kuuluvainen 2010). For example, modeling the forest-based sector as a group of interacting autonomous economic agents would make possible the analysis of the effects of forest-based disturbances on market dynamics (Schwab et al. 2009). In the ex-post evaluation of the French state's compensation plan after hurricane Klaus (Bavard et al. 2013), a bio-economic partial equilibrium model (Caurla et al. 2010) was used to compare a set of alternative management scenarios through varying output variables, such as prices and timber volume. This approach is very promising for supporting strategic decision-making, for example, to assess alternative strategies for timber export and storage (Caurla et al. 2015). In this context, a main challenge is to improve the reporting of economic data to help expost assessments and build models to predict the economic impact of storms on both individual agents and the forest-based sector as a whole. 


\subsection{Supporting systemic decision-making}

Those challenges also emphasize the need for a portfolio of decision support systems (DSS) where decision-makers can find appropriate tips. An illustration of how system analysis can drive the strategic management of storm damage is presented below. In this example, taking place in Wallonia (Belgium), a decision support system based on system dynamics principle, the WIND-STORM software (Riguelle et al. 2015), is used to predict how transport capacity and timber storage may influence the amount of timber lying in forests and industrial log yards during a 5-year period after a destructive storm. Four scenarios have been simulated, on the basis of an overall damage of eight million cubic meters: a baseline scenario, for which no specific measure is taken after the storm (BASE); a second scenario where only the harvesting capacity is boosted by $20 \%$ (SC1); a third in which both harvesting and transport capacities are increased by $20 \%$ (SC2); and a fourth where two million cubic meters of damaged timber are stored for 24 months (SC3).

Simulations show that transport capacity is lacking even in the baseline scenario and is therefore a systemic bottleneck (Fig. 4a-BASE). As transport capacity is a limiting factor, efforts to improve salvage logging have a limited impact as the harvested timber is progressively accumulating in the forest areas (Fig. $4 \mathrm{a}-\mathrm{SC} 1$ ), which increases the risk of secondary damage. Doubling the transport capacity can nullify the stock in forests, but it causes accumulation of timber in log yards (Fig. 4-SC2). Timber storage is able to alleviate the accumulation of harvested wood in the forests and preserve it from decay; however, as seen in Fig. 4b, too rapid destocking can cause an excessive supply if no measures to limit the upstream offer are taken. Interested readers should refer to Riguelle et al. (2015) for a thorough description of this type of DSS and its contribution to systemic analysis.

\section{Recommendations to public authorities}

This paper also offers an opportunity to highlight some of the main challenges for public authorities in supporting the forestbased sector in the context of integrated storm damage management. According to Fig. 2, public authorities could play an active role and beyond, and they should be the catalysts of this process. Five key challenges are briefly discussed:

- Improving public risk governance and awareness

- Developing an integrated policy for forests risk management

- Enhancing systemic resilience of the forest-based sector

- Facilitating the implementation of decisions

- Playing an active role in windthrow crisis management
Improving public risk governance and crisis management awareness is a prerequisite to be ready to cope with exceptional events (Mortier and Bartet 2004). Solutions to promote a risk awareness culture within public organizations could involve making knowledge of risk management issues a selection criterion when recruiting high-level officials, conducting risk surveys and audits, providing trainings and workshops to the staff, and organizing frequent crisis exercises. Moreover, the need for integrated policy of forest risk management is not only a challenge for the forest-based sector but also for the public authorities. They must provide the guidelines according to which the forest sector develops its own strategy. For example, they must clearly indicate what losses the policy will cover in case of damage. The challenge is to find the optimal share between public and private compensation (Nicolas 2009). Some governments used to undertake large interventions; nowadays, direct financial support to the forest-based sector is likely to be restricted by the EU's competition law. In addition, public compensation after windstorms may be counterproductive assuming it curbs stakeholders investing in riskreducing options at the individual level (Brunette and Couture 2008). On the other hand, insurance that could help to alleviate pressures for public compensation in the aftermath of natural disasters (European Commission 2013b) are not widespread in the forest sector. Whether there is any ideal framework to share the economic risk due to various forest ownership patterns and habits, the forest-based sector requires a clear view on what they can expect back from public authorities if they subscribe to insurance or self-insurance programs.

Public authorities should also take initiatives to improve the systemic resistance and resilience of the forest-based sector. Whether they have any direct influence on the macro-economic context, they can act locally by alleviating the constraints with which the forest-based sector struggles. In parallel, they should identify institutional bottlenecks and try to resolve them in advance by leading on prospective systemic analyses (Riguelle et al. 2015). The continuous improvement of the system also requires consistent and systematic ex-post evaluations of public policies (Bisang and Zimmermann 2006).

In addition, public authorities should act to facilitate the effective implementation of decisions. This begins with a flexible decision-making context that can be adapted throughout the crisis period. It also means simplifying administrative processes and ensuring that all the stakeholders within the decision-making chains, not only the forest agencies, are aware of their role (Raetz 2004). For instance, ministerial orders or authorizations that are not issued on time have slowed down recovery in the past (Lesbats 2002; Nicolas 2009). The public authorities must also communicate on their strategy, the choices made, and the underlying long-term vision to facilitate the acceptance and the implementation of their strategy (Bavard et al. 2013). 
Fig. 4 Example of systemic analysis supporting strategic decision after windstorms. a Stock of timber in the forest areas. b Stock of timber in log yards

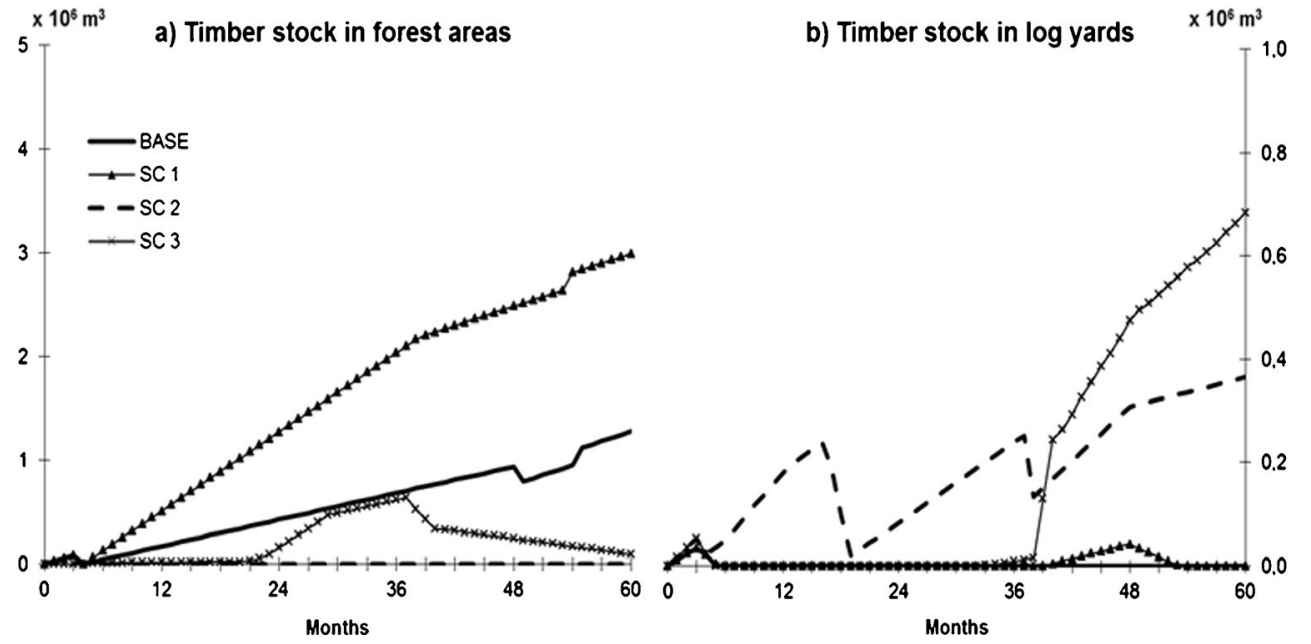

Finally, public authorities should invest money and human resources actively in windthrow crises management in order to ease the implementation of strategic decisions. On the one hand, they should set up contingency plans and improve them continuously following "Plan-Do-Check-Act" principle. On the other hand, public authorities could play a crucial role in regulating the timber market, for instance by mutualizing timber sales to stabilize stumpage prices. To be effective, forest agencies should be the first in line to support market facilities, by reducing the public timber offer or postponing payment delays, for instance. The main operational challenge for public authorities is to anticipate and prepare timber storage operations (Bavard et al. 2013; Birot and Gardiner 2013). This implies, among other things, identifying potential storage areas and developing a mutualized management framework to pool the costs and limit the fees for public and private owners.

\section{Conclusion}

In this paper, several sources of information were combined to draw a global picture of the current issues and opportunities concerning strategic decision-making and management of forest storm damage. We reached a conclusion that the forestbased sector has quite often a good perception of the windthrow phenomenon and is able to handle rapidly its consequences, owing to a strong empirical knowledge. Saving and sharing this knowledge, through contingency plans for instance, are essential, even more in countries that did not experience storm damage for decades. However, storm damage risk management cannot rely only on former crises, since the decisional context is changing and uncertain. Upcoming threats and opportunities arising from this uncertain context must be considered in the decisional process, as they will influence the way to deal with storm-related issues in the future. A way to reduce uncertainty in the aftermath of storms is to strengthen the resilience and resistance of the forestbased sector towards destructive storms, by addressing the main issues highlighted in this paper. Although some of these issues have already been addressed in some countries, this review can contribute to re-open the debate in order to foster the implementation of good practices and bridge remaining gaps at regional and national levels. Nevertheless, insofar as it is unrealistic to deliver a tailored solution for storm damage management, new approaches that could help to reduce the global impact of storm crises are also needed.

One way to deal with complexity and uncertainty throughout the risk management process would be to change perspectives and adopt an integrated management of storm risks, ideally as part of a wider analysis of forests' risks that could help to handle the multiplicity of risks coherently. However, because integrated approaches embrace many concepts, two prerequisites are highlighted: firstly, the forest community needs to develop advanced methodologies to deal with such complex issues and, on the other hand, dialogue among and outside the forest community must be enhanced. According to that, a systemic approach for storm damage management is also suggested in this paper to deal with the forest-based sector as a dynamic system. This holistic approach assumes that the strategy will not be optimal if some individuals are suffering from crisis conditions within the system. In contrast, a balanced solution for the whole sector will likely benefit all stakeholders individually. The resulting idea is to evaluate all possible mitigation scenarios through a systemic perspective, with the help of appropriate decision support systems. This approach requires, however, identifying the scope (regional, national, or supranational) and the internal and external drivers of the system at stake.

Finally, we insist on the role of public authorities in supporting windthrow crisis management at the European, 
national, and regional levels. On the one hand, public decision-makers should foster the development of an integrated policy about forest risks and take part more actively in the storm damage management process. Nevertheless, such active involvement requires enhancing risk culture within politics and public bodies. Furthermore, it is also crucial to ensure the mobilization of decision-holders (ministers and highlevel officials), and not only the institutional players. On the other hand, high transparency in public policy- and decisionmaking processes is needed to build confidence between the forest community and public authorities. Public authorities should also be the drivers for enhancing cooperation and reducing competition between bordering countries, which remains a major impediment in post-storm crisis periods. In regard to this challenge, the European Forest Strategy (European Commission 2013a) targets enhanced cooperation between member states and facilitates the coherence of forestrelated policies in Europe, whereas the building of an European Forest Risk Facility (Landmann et al. 2015) illustrates that the forest community actively concurs with the need for a better collaboration between stakeholders inside the forest sector and with decision-makers.

Acknowledgments The work was financially supported by the Public Service of Wallonia (SPW, Belgium).

\section{References}

Ananda J, Herath G (2003) The use of analytic hierarchy process to incorporate stakeholder preferences into regional forest planning. Forest Policy Econ 5:13-26. doi:10.1016/S1389-9341(02)00043-6

Ananda J, Herath G (2009) A critical review of multi-criteria decision making methods with special reference to forest management and planning. Ecol Econ 68:2535-2548. doi:10.1016/j.ecolecon.2009. 05.010

Angst C, Volz R (2002) A decision-support tool for managing stormdamaged forests. For Snow Landsc Res 77:217-224

Aven T (2009) Perspectives on risk in a decision-making context-review and discussion. Saf Sci 47:798-806. doi:10.1016/j.ssci.2008. 10.008

Aven T, Kristensen V (2005) Perspectives on risk: review and discussion of the basis for establishing a unified and holistic approach. Reliab Eng Syst Saf 90:1-14. doi:10.1016/j.ress.2004.10.008

Barredo JI (2010) No upward trend in normalised windstorm losses in Europe: 1970-2008. Nat Hazards Earth Syst Sci 10:97-104. doi:10. 5194/nhess-10-97-2010

Bartet J-H, Mortier F (2002) Guide : Gérer la crise "Chablis". Office National des Forêts, Paris

Barthod C, Barrillon A (2002) L'Etat au secours de la forêt : le plan gouvernemental. Rev for fr LIV:41-65. doi: 10.4267/2042/4986

Baur P, Holthausen N, Roschewitz A, Bernath K (2004) Tempetes en forêt. En quoi l'économie forestière se distingue des autres secteurs. Forêt 10:11-15

Bavard D, de Lagarde O, Magrum M (2013) Évaluation du volet mobilisation des bois chablis-Plan de solidarité nationale consécutif à la tempête Klaus du 24 janvier 2009. Conseil général de l'alimentation, de l'agriculture et des espaces ruraux (CGAAER), Paris
Beck U (1992) Risk society : towards a new modernity. Sage Publications, London

Beierle TC (2002) The quality of stakeholder-based decisions. Risk Anal 22:739-749

Birot Y (2002) Tempêtes et forêts : perturbations, catastrophes ou opportunités? Ann Mines Août 2002:96-102

Birot Y, Gollier C (2001) Risk assessment, management and sharing in forestry, with special emphasis on windstorms. In: Kokkonen O (ed) Proceedings of 14th Convocation of the International Council of Academies of Engineering and Technological Sciences (CAETS), Espoo

Birot Y, Gardiner B (2013) Challenges for forestry in relation to storms. In: Gardiner B, Schuck A, Schelhaas M-J, Orazio C, Blennow K, Nicoll B (eds) Living with storm damage to forests. European Forest Institute, Joensuu, pp 123-129

Birot Y, Landmann G, Bonhême I (2009) La forêt face aux tempêtes. Quae, Versailles

Bisang K, Zimmermann W (2006) Key concepts and methods of programme evaluation and conclusions from forestry practice in Switzerland. Forest Policy Econ 8:502-511. doi:10.1016/j.forpol. 2005.07.002

Björheden R (2007) Possible effects of the hurricane Gudrun on the regional Swedish forest energy supply. Biomass Bioenerg 31:617622. doi:10.1016/j.biombioe.2007.06.025

Blennow K (2008) Risk management in Swedish forestry-policy formation and fulfillment of goals. J Risk Res 11:237-254. doi:10.1080/13669870801939415

Blennow K, Persson E (2013) Societal impacts of storm damage. In: Gardiner B, Schuck A, Schelhaas M-J, Orazio C, Blennow K, Nicoll B (eds) Living with storm damage to forests. European Forest Institute, Joensuu, pp 70-78

Blennow K, Sallnäs O (2005) Decision support for active risk management in sustainable forestry. J Sustain For 21:201-212. doi:10.1300/ J091v21n02-12

Blennow K, Persson J, Wallin A, Vareman N, Persson E (2014) Understanding risk in forest ecosystem services: implications for effective risk management, communication and planning. Forestry 87:219-228. doi:10.1093/forestry/cpt032

Bossel H (Coord.) (2002) Assessing viability and sustainability: a systems-based approach for deriving comprehensive indicator sets. Conserv Ecol. http://www.consecol.org/vol5/iss2/art12/. Accessed 9 May 2016

Bouget C, Duelli P (2004) The effects of windthrow on forest insect communities: a literature review. Biol Conserv 118:281-299. doi: 10.1016/j.biocon.2003.09.009

Broman H, Frisk M, Rönnqvist M (2009) Supply chain planning of harvest and transportation operations after the storm Gudrun. INFOR 47:235-245

Bründl M, Rickli C (2002) The storm Lothar 1999 in Switzerland - an incident analysis. For Snow Landsc Res 77:207-216

Brunet S (2007) Société du risque: quelles réponses politiques ? L'Harmattan, Paris

Brunette M, Couture S (2008) Public compensation for windstorm damage reduces incentives for risk management investments. Forest Policy Econ 10:491-499. doi:10.1016/j.forpol.2008.05.001

Brunette M, Holecy J, Sedliak M, Tucek J, Hanewinkel M (2015) An actuarial model of forest insurance against multiple natural hazards in fir (Abies Alba Mill.) stands in Slovakia. Forest Policy Econ 55: 46-57. doi:10.1016/j.forpol.2015.03.001

Buttoud G (2000) How can policy take into consideration the "full value" of forests? Land Use Policy 17:169-175. doi:10.1016/S02648377(00)00015-6

Buttoud G, Kouplevatskaya-Buttoud I, Slee B, Weiss G (2011) Barriers to institutional learning and innovations in the forest sector in Europe: markets, policies and stakeholders. Forest Policy Econ 13:124-131. doi:10.1016/j.forpol.2010.05.006 
Campbell B, Sayer JA, Frost P, Vermeulen S, Ruiz-Pérez M, Cunningham T, Prabhu R (2002) Assessing the performance of natural resource systems. Conserv Ecol. http://www.consecol.org/vol5/iss2/art22/. Accessed 9 May 2016

Campioli M, Vincke C, Jonard M, Kint V, Demarée G, Ponette Q (2012) Current status and predicted impact of climate change on forest production and biogeochemistry in the temperate oceanic European zone: review and prospects for Belgium as a case study. J For Res 17:1-18. doi:10.1007/s10310-011-0255-8

Canadell JG, Raupach MR (2008) Managing forests for climate change mitigation. Science 320:1456-1457. doi:10.1126/science.1155458

Caurla S, Lecocq F, Delacote P, Barkaoui A (2010) The French forest sector model: version 1.0. Presentation and theorical foundations. Laboratoire d'Economie Forestière, Nancy

Caurla S, Garcia S, Niedzwiedz A (2015) Store or export? An economic evaluation of financial compensation to forest sector after windstorm. The case of hurricane Klaus. Forest Policy Econ 61:30-38. doi:10.1016/j.forpol.2015.06.005

Chtioui Y, Kaulfuß S, Hartebrodt C (2015) Forest crisis management advisory guide. Forest Research Institut Baden-Württemberg (FVA). http://www.waldwissen.net/waldwirtschaft/schaden/fva ratgeber_forstliches krisenmanagement_startseite/index_EN. Accessed 15 Mar $201 \overline{6}$

Corvol A (2005) Tempêtes sur la forêt française. L'Harmattan, Paris

Costa S, Ibanez L (2005) Can wood storage be profitable? French experience after the windstorms in 1999. J For Econ 11:161-176. doi:10. 1016/j.jfe.2005.08.001

de Rosnay J (1997) Analytic vs. systemic approaches. In: Heylighen F, Joslyn C, Turchin V (eds) Principia Cybernetica web, Principia Cybernetica, Brussels http://pespmc1.vub.ac.be/analsyst.html

Diaz-Balteiro L, Romero C (2008) Making forestry decisions with multiple criteria: a review and an assessment. For Ecol Manag 255: 3222-3241. doi:10.1016/j.foreco.2008.01.038

Direction des Forêts (1987) Les réactions des pouvoirs publics lors de la tempête des 6, 7 et 8 novembre 1982. Rev For Fr 39:257-268. doi: $10.4267 / 2042 / 25795$

Drouineau S, Laroussinie O, Birot Y, Terrasson D, Formery T, RomanAmat B (2000) Expertise collective sur les tempêtes, la sensibilité des forêts et leur reconstitution. INRA-MES, Paris

Dymond C, Spittlehouse D, Tedder S, Hopkins K, McCallion K, Sandland J (2015) Applying resilience concepts in forest management: a retrospective simulation approach. Forests 6:4377. doi:10.3390/f6124377

European Commission (2013a) Communication from the Commission to the European Parliament, the Council, the European Economic and Social Committee and the Committee of Regions. A new EU Forest Strategy: for forests and the forest-based sector. COM (2013) 659 final

European Commission (2013b) Green paper on the insurance of natural and man-made disasters. COM (2013) 213 final

FAO/ECE/ILO (1996) Manual on acute forest damage - managing the impact of sudden and severe forest damage. United Nations, Geneva

Fares S, Scarascia Mugnozza G, Corona P, Palahí M (2015) Five steps for managing Europe's forests. Nature 519:407-409

Fermet-Quinet S (2013) Outils institutionnels, systèmes et organisation pour l'anticipation, le suivi et la gestion des risques naturels dans les forêts du Sud-Ouest de l'Europe. Diagnostic de la gestion du risque sanitaire. Mémoire de dominante forestière, ENGREFAgroParisTech

FIBOIS (2010a) Actions préventives et propositions d'organisation de la filière en cas de nouvel aléa climatique. FIBOIS Alsace, Schiltigheim

FIBOIS (2010b) Traduction opérationnelle de l'audit tempête. Rapport final. FIBOIS Alsace, Schiltigheim

Fink AH, Brücher T, Ermert V, Krüger A, Pinto JG (2009) The European storm Kyrill in January 2007: synoptic evolution, meteorological impacts and some considerations with respect to climate change. Nat Hazards Earth Syst Sci 9:405-423. doi:10.5194/nhess-9-4052009

Fischbacher U, Gächter S (2010) Social preferences, beliefs, and the dynamics of free riding in public goods experiments. Am Econ Rev 100:541-556. doi:10.1257/aer.100.1.541

Forest Windblow Action Committee (1988) Guidelines for dealing with windblow in woodlands: marketing, sale and restocking in woods damaged by the storm of 16th October 1987. Forest Research Station, Farnham Surrey

Forestry Commission Scotland (2014) Scottish windblow contingency plan. Forestry Commission Scotland, Edinburgh

Gamper CD, Turcanu C (2009) Can public participation help managing risks from natural hazards? Saf Sci 47:522-528. doi:10.1016/j.ssci. 2008.07.005

Garcia-Gonzalo J, Palma J, Freire J, Tomé M, Mateus R, Rodriguez LCE, Bushenkov V, Borges JG (2013) A decision support system for a multi stakeholder's decision process in a Portuguese national forest. For Syst 22:359-373. doi:10.5424/fs/2013222-03793

Gardiner BA, Quine CP (2000) Management of forests to reduce the risk of abiotic damage - a review with particular reference to the effects of strong winds. For Ecol Manag 135:261-277. doi:10.1016/S03781127(00)00285-1

Gardiner B, Blennow K, Carnus J-M, Fleischer M, Ingemarson F, Landmann G, Lindner M, Marzano M, Nicoll B, Orazio C, Peyron J-L, Reviron M-P, Schelhaas M-J, Schuck A, Spielmann M, Usbeck $\mathrm{T}$ (2010) Destructive storms in European forests: past and forthcoming impacts. Final report to the European Commission-DG Environment. European Forest Institute, Joensuu

Gardiner B, Schuck A, Schelhaas M-J, Orazio C, Blennow K, Nicoll B (2013) Living with storm damage to forests. European Forest Institute, Joensuu

GIP ECOFOR (2010) Retour sur la gestion de crise suite à la tempête Klaus et éléments d'anticipation. Expertise sur l'avenir du massif forestier des Landes de Gascogne, Rapport de synthèse Groupe de travail 1. GIP ECOFOR, Paris

Gopalakrishnan C, Okada N (2007) Designing new institutions for implementing integrated disaster risk management: key elements and future directions. Disasters 31:353-372. doi:10.1111/j.14677717.2007.01013.x

Grayson AJ (1989) The 1987 storm. Impacts and responses. Forestry Commission Bulletin 87. Her Majesty's Stationery Office, London

Greiving S, Pratzler-Wanczura S, Sapountzaki K, Ferri F, Grifoni P, Firus $\mathrm{K}$, Xanthopoulos G (2012) Linking the actors and policies throughout the disaster management cycle by "agreement on objectives" - a new output-oriented management approach. Nat Hazards Earth Syst Sci 12:1085-1107. doi:10.5194/nhess-12-1085-2012

Haimes YY (2011) Risk modeling, assessment, and management. Wiley, Hoboken

Hammer S, Schmidt N, Iten R (2003) Lothar: kantonale Strategien. Umwelt-Materialien Nr. 154. Bundesamt für Umwelt, Wald und Landschaft (BUWAL), Bern

Hanewinkel M, Hummel S, Albrecht A (2011) Assessing natural hazards in forestry for risk management: a review. Eur J For Res 130:329 351. doi:10.1007/s10342-010-0392-1

Hänsli C, Keel A, Kissling-Näf I, Zimmermann W (2003) Lothar sturmschäden im wald, 1999. Eine vergleichende analyse der politischen prozesse und der staatlichen massnahmen nach «Lothar» und «Martin» in der Schweiz, Deutschland und Frankreich - Synthesebericht. Umwelt-Materialien Nr. 159. Bundesamt für Umwelt, Wald und Landschaft (BUWAL), Bern

Harmer R (2012) What happened in the woods? Weather 67:261-265. doi: $10.1002 /$ wea. 1948

Hartebrodt C (2014) Essentials of practical forest crisis management. Forest Research Institute Baden-Württemberg, Freiburg 
Heinonen T, Pukkala T, Ikonen VP, Peltola H, Venäläinen A, Dupont S (2009) Integrating the risk of wind damage into forest planning. For Ecol Manag 258:1567-1577. doi:10.1016/j.foreco.2009.07.006

Heylighen F, Joslyn C (1992) What is systems theory? In: Heylighen F, Joslyn C, Turchin V (eds) Principia Cybernetica Web, Principia Cybernetica, Brussels http://pespmc1.vub.ac.be/SYSTHEOR.html

Holecy J, Hanewinkel M (2006) A forest management risk insurance model and its application to coniferous stands in southwest Germany. Forest Policy Econ 8:161-174. doi:10.1016/j.forpol. 2004.05.009

Holmes TP, Prestemon JP, Abt KL (2008) The economics of forest disturbances: wildfires, storms, and invasive species. Springer Netherlands, Dordrecht

Honkavaara E, Litkey P, Nurminen K (2013) Automatic storm damage detection in forests using high-altitude photogrammetric imagery. Remote Sens 5:1405-1424. doi:10.3390/rs5031405

IPPC (2012) Managing the risks of extreme events and disasters to advance climate change adaptation. A special report of Working Groups I and II of the Intergovernmental Panel on Climate Change. Field CB, Barros V, Stocker TF, Qin D, Dokken DJ, Ebi KL, Mastrandrea MD, Mach KJ, Plattner G-K, Allen SK, Tignor M, Midgley PM (eds) Cambridge University Press, Cambridge

ISO 31000 (2009) Risk management-principles and guidelines. International Organization for Standardization, Geneva

Jactel H, Nicoll BC, Branco M, Gonzalez-Olabarria JR, Grodzki W, Långström B, Moreira F, Netherer S, Orazio C, Piou D, Santos H, Schelhaas MJ, Tojic K, Vodde F (2009) The influences of forest stand management on biotic and abiotic risks of damage. Ann For Sci 66:701-719. doi:10.1051/forest/2009054

Kamimura K, Shiraishi N (2007) A review of strategies for wind damage assessment in Japanese forests. J For Res 12:162-176. doi:10.1007/ s10310-007-0005-0

Kaplan S, Garrick BJ (1981) On the quantitative definition of risk. Risk Anal 1:11-27. doi:10.1111/j.1539-6924.1981.tb01350.x

Keenan R (2015) Climate change impacts and adaptation in forest management: a review. Ann For Sci 72:145-167. doi:10.1007/s13595014-0446-5

Laffite J-J, Lerat J-F (2009) Reconstitution des peuplements forestiers détruits par la tempête du 24 janvier 2009 dans le massif forestier des Landes de Gascogne. Conseil général de l'agriculture, de l'alimentation et des espaces ruraux (CGAAER), Paris

Lagergren F, Jönsson AM, Blennow K, Smith B (2012) Implementing storm damage in a dynamic vegetation model for regional applications in Sweden. Ecol Model 247:71-82. doi:10.1016/j.ecolmodel. 2012.08.011

Lal P, Lim-Applegate H, Scoccimarro MC (2002) The adaptive decisionmaking process as a tool for integrated natural resource management: focus, attitudes, and approach. Conserv Ecol. http:/www. consecol.org/vol5/iss2/art11/. Accessed 9 May 2016

Landmann G, Held A, Schuck A, Van Brusselen J (eds) (2015) European forests at risk. A scoping study in support of the development of a European forest risk facility. European Forest Institute, Joensuu

Lesbats R (2002) Les conséquences des tempêtes de décembre 1999 sur la filière bois : des enseignements à en tirer. Conseil économique et social, Paris

Lesgourgues Y, Drouineau S (2009) Un plan d'urgence pour la filière pin maritime. CIPM, Bordeaux

Lindner M, Maroschek M, Netherer S, Kremer A, Barbati A, GarciaGonzalo J, Seidl R, Delzon S, Corona P, Kolström M, Lexer MJ, Marchetti M (2010) Climate change impacts, adaptive capacity, and vulnerability of European forest ecosystems. For Ecol Manag 259: 698-709. doi:10.1016/j.foreco.2009.09.023

Lindroth A, Lagergren F, Grelle A, Klemedtsson L, Langvall OLA, Weslien PER, Tuulik J (2009) Storms can cause Europe-wide reduction in forest carbon sink. Glob Chang Biol 15:346-355. doi:10.1111/j.1365-2486.2008.01719.x

Lovell C, Mandondo A, Moriarty P (2002) The question of scale in integrated natural resource management. Conserv Ecol. http:// www.consecol.org/vol5/iss2/art25/. Accessed 9 May 2016

MAFF (1988) The effects of the great storm : report of a Technical Coordination Committee and the Government's response. Her Majesty's Stationery Office, London

Marques AF, Borges JG, Garcia-Gonzalo J, Lucas B, Melo I (2013a) A participatory approach to design a toolbox to support forest management planning at regional level. For Syst 22:340-358. doi:10.5424/ fs/2013222-03120

Marques AF, Fricko A, Kangas A, Rosset C, Ferreti F, Rasinmaki J, Packalen T, Gordon S (2013b) Empirical guidelines for forest management decision support systems based on the past experiences of the expert's community. For Syst 22:320-339. doi:10.5424/fs/ 2013222-03033

Mendoza GA, Martins H (2006) Multi-criteria decision analysis in natural resource management: a critical review of methods and new modelling paradigms. For Ecol Manag 230:1-22. doi:10.1016/j.foreco. 2006.03.023

Meyer V, Becker N, Markantonis V, Schwarze R, van den Bergh JCJM, Bouwer LM, Bubeck P, Ciavola P, Genovese E, Green C, Hallegatte S, Kreibich H, Lequeux Q, Logar I, Papyrakis E, Pfurtscheller C, Poussin J, Przyluski V, Thieken AH, Viavattene C (2013) Review article: assessing the costs of natural hazards - state of the art and knowledge gaps. Nat Hazards Earth Syst Sci 13:1351-1373. doi:10. 5194/nhess-13-1351-2013

Millar CI, Stephenson NL, Stephens SL (2007) Climate change and forests of the future: managing in the face of uncertainty. Ecol Appl 17: 2145-2151. doi:10.1890/06-1715.1

Mitchell SJ (2013) Wind as a natural disturbance agent in forests: a synthesis. Forestry 86:147-157. doi:10.1093/forestry/cps058

Moore JR, Manley BR, Park D, Scarrott CJ (2013) Quantification of wind damage to New Zealand's planted forests. Forestry 86:173-183. doi: 10.1093/forestry/cps076

Mortier F, Bartet JH (2004) Intégrons la culture de gestion de crise en milieu naturel notamment à la lumière de l'expérience des tempêtes de 1999. Rev For Fr 56:307-321. doi:10.4267/2042/5103

Munich Re (2002) Winter storms in Europe (II). Munich Re Group, München

Nabuurs GJ, Pussinen A, van Brusselen J, Schelhaas MJ (2007) Future harvesting pressure on European forests. Eur J For Res 126:391400. doi:10.1007/s10342-006-0158-y

Nicolas J-P (2009) Rapport d'information sur les conséquences de la tempête du 24 janvier 2009 dans le Sud-Ouest. Assemblée nationale, Paris

Nieuwenhuis M, O'connor E (2001) Financial impact evaluation of catastrophic storm damage in Irish forestry: a case study. I. Stumpage losses. Forestry 74:369-381. doi:10.1093/forestry/74.4.369

Nilsson S (2015) Is today's systems analysis up-to-date for today's and tomorrow's decision- and policy making? 16th Symposium for Systems Analysis in Forest Resources (SSAFR), Uppsala, Sweden, 19-21 August 2015

Odenthal-Kahabka J (2005) Storm handbook - coping with storm damaged timber. Forest Research Institut Baden-Württemberg (FVA). http://www.waldwissen.net/waldwirtschaft/schaden/sturm_schnee eis/fva_sturmhandbuch/index_EN. Accessed 12 Dec 2010

OFEV (2008) Aide-mémoire en cas de dégâts de tempête. Aide à l'exécution pour la maîtrise des dégâts dus à des tempêtes en forêt classées d'importance nationale. Office fédéral de l'environnement, Berne

O'Hara KL, Ramage BS (2013) Silviculture in an uncertain world: utilizing multi-aged management systems to integrate disturbance. Forestry 86:401-410. doi:10.1093/forestry/cpt012 
Oosterbaan A, van den Berg CA, de Boer T, de Jong JJ, Moraal LG, Niemeijer CM, Veerkamp M, Verkaik E (2009) Storm en bosbeheer: afwegingen voor het laten liggen of ruimen van stormhout. Wageningen UR, Alterra

Orazio C, Régolini M, Meredieu C, Gardiner B, Cantero A, Fermet-Quinet S, Hevia A, Branco M, Picard O (2014) Gestion intégrée des risques en forêt : l'expérience du projet FORRISK. Proceedings of Carrefours de l'innovation agronomique, Bordeaux, 3 décembre 2014

Payn T, Carnus J-M, Freer-Smith P, Kimberley M, Kollert W, Liu S, Orazio C, Rodriguez L, Silva LN, Wingfield MJ (2015) Changes in planted forests and future global implications. For Ecol Manag 352:57-67. doi:10.1016/j.foreco.2015.06.021

Petr M, Boerboom L, Ray D, van der Veen A (2014) An uncertainty assessment framework for forest planning adaptation to climate change. Forest Policy Econ 41:1-11. doi:10.1016/j.forpol.2013. 12.002

Peyron J-L, Blanchard G, Danguy des Déserts D (1999) Les tempêtes, une fatalité ? Rev For Fr LI:729-732. doi: 10.4267/2042/5680

Pinto JG, Fröhlich EL, Leckebusch GC, Ulbrich U (2007) Changing European storm loss potentials under modified climate conditions according to ensemble simulations of the ECHAM5/MPI-OM1 GCM. Nat Hazards Earth Syst Sci 7:165-175. doi:10.5194/nhess7-165-2007

Pischedda D (2004) Technical guide on harvesting and conservation of storm damaged timber. Concerted action QLK5-CT2001-00645 (STODAFOR project). CTBA, Paris

Prestemon JP, Holmes TP (2004) Market dynamics and optimal timber salvage after a natural catastrophe. For Sci 50:495-511

Raetz P (2004) Les enseignements de la gestion d'une crise. Synthèse du programme de recherche Lothar. Office fédéral de l'environnement, des forêts et du paysage (OFEFP), Berne

Rametsteiner E, Weiss G (2006a) Assessing policies from a systems perspecitve - experiences with applied innovation systems analysis and implications for policy evaluation. Forest Policy Econ 8:564 576. doi:10.1016/j.forpol.2005.07.005

Rametsteiner E, Weiss G (2006b) Innovation and innovation policy in forestry: linking innovation process with systems models. Forest Policy Econ 8:691-703. doi:10.1016/j.forpol.2005.06.009

Reynolds KM, Borges JG, Vacik H, Lexer MJ (2005) ICT in forest management and conservation. In: Hetemaki L, Nilsson S (eds) Information technology and the forest sector IUFRO world series volume 18. IUFRO, Vienna, pp 150-171

Reynolds KM, Twery M, Lexer MJ, Vacik H, Ray D, Shao G, Borges JG (2008) Decision support systems in natural resource management. In: Burnstein F, Holsapple C (eds) Handbook on decision support systems. Springer, Berlin, pp 499-534

Riguelle S (2010) Plan chablis - Guide pour la gestion des crises chablis en Wallonie. Service public de Wallonie, Jambes

Riguelle S, Hébert J, Jourez B, Rommelaere A (2011) Le plan chablis : un outil de planification d'urgence et de gestion de crise pour la forêt wallonne. Forêt Wallonne 111:3-9

Riguelle S, Hébert J, Jourez B (2015) WIND-STORM: a decision support system for the strategic management of windthrow crises by the forest community. Forests 6:3412-3432. doi:10.3390/f6103412

Sauter P, Möllmann T, Anastassiadis F, Musshoff O, Möhring B (2016) To insure forests assets or not? An analysis of foresters behavior. Proceedings of IUFRO Risk Analysis Meeting, Freiburg, Germany

Sayer JA, Campbell B (2002) Research to integrate productivity enhancement, environmental protection, and human development. Conserv Ecol. http://www.consecol.org/vol5/iss2/art32/. Accessed 9 May 2016

Schelhaas MJ, Nabuurs GJ, Schuck A (2003) Natural disturbances in the European forests in the 19th and 20th centuries. Glob Chang Biol 9: 1620-1633. doi:10.1046/j.1529-8817.2003.00684.x

Schelhaas MJ, Hengeveld G, Moriondo M, Reinds GJ, Kundzewicz ZW, ter Maat H, Bindi M (2010) Assessing risk and adaptation options to fires and windstorms in European forestry. Mitig Adapt Strateg Glob Chang 15:681-701. doi:10.1007/s11027-010-9243-0

Schou E, Thorsen BJ, Jacobsen JB (2015) Regeneration decisions in forestry under climate change related uncertainties and risks: effects of three different aspects of uncertainty. Forest Policy Econ 50:1119. doi:10.1016/j.forpol.2014.09.006

Schwab O, Maness T, Bull G, Roberts D (2009) Modeling the effect of changing market conditions on mountain pine beetle salvage harvesting and structural changes in the British Columbia forest products industry. Can J For Res 39:1806-1820. doi:10.1139/X09-099

Schwarzbauer P, Rauch P (2013) Impact on industry and markets - roundwood prices and procurement risks. In: Gardiner B, Schuck A, Schelhaas M-J, Orazio C, Blennow K, Nicoll B (eds) Living with storm damage to forests. European Forest Institute, Joensuu, pp 64-69

Schwarzbauer P, Weinfurter S, Stern T, Koch S (2013) Economic crises: impacts on the forest-based sector and wood-based energy use in Austria. Forest Policy Econ 27:13-22. doi:10.1016/j.forpol.2012. 11.004

Schwierz C, Köllner-Heck P, Zenklusen Mutter E, Bresch D, Vidale P-L, Wild M, Schär C (2010) Modelling European winter wind storm losses in current and future climate. Clim Chang 101:485-514. doi:10.1007/s10584-009-9712-1

Segura M, Ray D, Maroto C (2014) Decision support systems for forest management: a comparative analysis and assessment. Comput Electron Agric 101:55-67. doi:10.1016/j.compag.2013.12.005

Seidl R, Lexer MJ (2013) Forest management under climatic and social uncertainty: trade-offs between reducing climate change impacts and fostering adaptive capacity. J Environ Manag 114:461-469. doi:10.1016/j.jenvman.2012.09.028

Spathelf P, Maaten E, Maaten-Theunissen M, Campioli M, Dobrowolska D (2014) Climate change impacts in European forests: the expert views of local observers. Ann For Sci 71:131-137. doi:10.1007/ s13595-013-0280-1

Stadelmann G, Bugmann H, Meier F, Wermelinger B, Bigler C (2013) Effects of salvage logging and sanitation felling on bark beetle (Ips typographus L.) infestations. For Ecol Manag 305:273-281. doi:10. 1016/j.foreco.2013.06.003

Subramanian N, Bergh J, Johansson U, Nilsson U, Sallnäs O (2015) Adaptation of forest management regimes in Southern Sweden to increased risks associated with climate change. Forests 7:8

Swedish Forest Agency (2006) After Gudrun. Lessons learnt following the storm in 2005 and recommendations for the future. Swedish Forest Agency, Jönköping

Thom D, Seidl R, Steyrer G, Krehan H, Formayer H (2013) Slow and fast drivers of the natural disturbance regime in Central European forest ecosystems. For Ecol Manag 307:293-302. doi:10.1016/j.foreco. 2013.07.017

Toppinen A, Kuuluvainen J (2010) Forest sector modelling in Europethe state of the art and future research directions. Forest Policy Econ 12:2-8. doi:10.1016/j.forpol.2009.09.017

Trauman D (2002) Le retour d'expériences: outils et concepts. Ann Mines Août 2002:3-7

Usbeck T, Wohlgemuth T, Dobbertin M, Pfister C, Bürgi A, Rebetez M (2010) Increasing storm damage to forests in Switzerland from 1858 to 2007. Agric For Meteorol 150:47-55. doi:10.1016/j.agrformet. 2009.08.010

Valinger E, Kempe G, Fridman J (2014) Forest management and forest state in southern Sweden before and after the impact of storm Gudrun in the winter of 2005. Scand J For Res 29:1-7. doi:10. $1080 / 02827581.2014 .927528$

van Lierop P, Lindquist E, Sathyapala S, Franceschini G (2015) Global forest area disturbance from fire, insect pests, diseases and severe weather events. For Ecol Manag 352:78-88. doi:10.1016/j.foreco. 2015.06.010 
Veenman S, Liefferink D, Arts B (2009) A short history of Dutch forest policy: the 'de-institutionalisation' of a policy arrangement. Forest Policy Econ 11:202-208. doi:10.1016/j.forpol. 2009.03.001

Verkerk PJ, Levers C, Kuemmerle T, Lindner M, Valbuena R, Verburg $\mathrm{PH}$, Zudin S (2015) Mapping wood production in European forests. For Ecol Manag 357:228-238. doi:10.1016/j.foreco.2015.08.007

Wermelinger B, Duelli P, Obrist MK (2002) Dynamics of saproxylic beetles (Coleoptera) in windthrow areas in alpine spruce forests. For Snow Landsc Res 77:133-148

Wermelinger B, Obrist MK, Baur H, Jakoby O, Duelli P (2013) Synchronous rise and fall of bark beetle and parasitoid populations in windthrow areas. Agric For Entomol 15:301-309. doi:10.1111/ afe. 12018
Winkel G, Sotirov M (2015) Whose integration is this? European forest policy between the gospel of coordination, institutional competition, and a new spirit of integration. Environ Plan C. doi:10.1068/c1356j

Yousefpour R, Bredahl Jacobsen J, Thorsen BJ, Meilby H, Hanewinkel M, Oehler K (2012) A review of decision-making approaches to handle uncertainty and risk in adaptive forest management under climate change. Ann For Sci 69:1-15. doi:10.1007/s13595-011-0153-4

Yousefpour R, Temperli C, Bugmann H, Elkin C, Hanewinkel M, Meilby H, Jacobsen JB, Thorsen BJ (2013) Updating beliefs and combining evidence in adaptive forest management under climate change: a case study of Norway spruce (Picea abies L. Karst) in the Black Forest, Germany. J Environ Manag 122:56-64. doi:10.1016/j. jenvman.2013.03.004 